\title{
Regulation of lung oxidative damage by endogenous superoxide dismutase in sepsis
}

\author{
Larissa Constantino ${ }^{1}$, Renata Casagrande Gonçalves ${ }^{1}$, Vinícius Renê Giombelli ${ }^{1}$, Cristiane Damiani Tomasi ${ }^{1}$, \\ Francieli Vuolo ${ }^{1}$, Luiza Wilges Kist ${ }^{2}$, Giovanna Medeiros Tavares de Oliveira ${ }^{2}$, Matheus Augusto de Bittencourt Pasquali' \\ Maurício Reis Bogo ${ }^{2}$, Thais Mauad ${ }^{4}$, Adolfo Horn $\mathrm{Jr}^{5}$, Karen V Melo ${ }^{5}$, Christiane Fernandes, \\ José Cláudio Fonseca Moreira ${ }^{3}$, Cristiane Ritter ${ }^{1}$ and Felipe Dal-Pizzol ${ }^{*}$
}

\footnotetext{
* Correspondence: piz@unesc.net ${ }^{1}$ Laboratório de Fisiopatologia Experimenta e Instituto Nacional de Ciência e Tecnologia Translacional em Medicina (INCT-TM), Programa de Pós-Graduação de Ciências da Saúde Universidade do Extremo Sul Catarinense, Avenida Universitária, 1105, Criciúma, SC 88806-000, Brazil Full list of author information is available at the end of the article
}

\begin{abstract}
Background: The purpose of this research is to study the relationship between superoxide dismutase (SOD) and lung redox state in an animal model of sepsis.

Methods: Sepsis was induced in rats by the cecal ligation and perforation model (CLP). After 3, 6, and 12 h, CLP protein content and expression of SOD1, SOD2, and SOD3 were evaluated, and SOD activity was assessed. Oxidative damage was determined by quantifying nitrotyrosine content. Lung localization of SOD3 was performed by immunohistochemistry. The protective effect of a SOD mimetic on oxidative damage, inflammation, and lung permeability was assessed 12 and $24 \mathrm{~h}$ after sepsis induction.

Results: Lung levels of SOD1 decreased 3 and $12 \mathrm{~h}$ after sepsis, but SOD2 and SOD3 increased, as well as SOD activity. These alterations were not associated with changes in sod gene expression. Nitrotyrosine levels increased 3 and $12 \mathrm{~h}$ after sepsis. The administration of a SOD mimetic decreased nitrotyrosine and proinflammatory cytokine levels and improved lung permeability.
\end{abstract}

Conclusions: SOD2 and SOD3 increased after sepsis induction, but this was insufficient to protect the lung. Treatments based on SOD mimetics could have a role in lung injury associated with sepsis.

Keywords: Sepsis; SOD; NO; Lung; Redox state; SOD mimetic

\section{Background}

Several molecular mechanisms of inflammation and cellular damage have been implicated in the pathogenesis of sepsis including excessive reactive oxygen species (ROS) generation [1]. Main sources of ROS in the lung during sepsis are inflammatory cells and mitochondria [2,3]. Production of ROS leads to lipid, protein, and extracellular matrix damage, which increases pulmonary inflammation $[4,5]$.

Antioxidants are known to counteract the deleterious effects of ROS. Superoxide dismutase (SOD) is a component of antioxidant response and catalyzes the conversion of superoxide anions to hydrogen peroxide [6]. Three SODs are found in mammals and regulate the concentration of superoxide: a cytosolic (SOD1), a mitochondrial (SOD2), and an extracellular (SOD3), which bind to both cell surfaces and extracellular matrices [7]. sod3 gene is highly expressed in the lung, where it plays a major protective role by controlling oxidative stress and inflammation and regulating redox homeostasis of

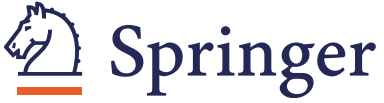

(c) 2014 Constantino et al.; licensee Springer. This is an Open Access article distributed under the terms of the Creative Commons Attribution License (http://creativecommons.org/licenses/by/4.0), which permits unrestricted use, distribution, and reproduction in any medium, provided the original work is properly credited. 
the airways [8]. Localization of SOD3 in the lung depends on its ability to bind to the extracellular matrix by a heparan sulfate domain, which can be fragmented by oxidative damage [5,9]. Furthermore, extracellular matrix fragments stimulate inflammatory cell migration, which is of concern since matrix components are widely distributed throughout the interstitium [9]. Proteolytic cleavage of SOD3's anchorage domain alters its tissue distribution and, consequently, the oxidant/antioxidant balance [10].

In addition, bioactivity of nitric oxide (NO) partially depends on its interaction with ROS, particularly superoxide anions [11]. NO reacts with superoxide to form peroxynitrite $\left(\mathrm{ONOO}^{-}\right)$, which induces protein oxidation and DNA damage [12]. SOD3 prevents the inactivation of NO by superoxide; therefore, an increase in sod3 expression in blood vessels preserves endothelial function by overcoming oxidative stresses [13]. Furthermore, several evidences suggest that SOD3 may have a protective role against inflammation [10,14].

Thus, it was hypothesized that endogenous SOD3 could have a major role in lung defenses against oxidative stress during sepsis development. The aims of this study are (1) to determine if there is a relationship between the expression and activity of SOD and the occurrence of oxidative stress and (2) to determine if the administration of a SOD mimetic is able to prevent lung damage in an animal model of sepsis.

\section{Methods}

Animals

Three-month-old male Wistar rats (350 to $400 \mathrm{~g}$ ) were obtained from our breeding colony. The rats were caged in groups of five, had free access to food and water, and were maintained on a 12-h light-dark cycle (600 to 1800 hours) in a temperature-controlled colony room $\left(22^{\circ} \mathrm{C} \pm 1^{\circ} \mathrm{C}\right)$. The research protocol was approved by the Ethical Committee for Animal Experimentation of Universidade do Extremo Sul Catarinense under protocol number 21/2011.

\section{Cecal ligation and perforation surgery}

The animals were subjected to cecal ligation and perforation (CLP) as previously described [15]. Briefly, the rats were anesthetized with ketamine $(80 \mathrm{mg} / \mathrm{kg})$. Under aseptic conditions, a 3-cm midline laparotomy was performed to allow exposure of the cecum with the adjoining intestine. The cecum was tightly ligated with a 3.0 silk suture at its base (below the ileocecal valve) and was then perforated a single time with a 14-gauge needle. The cecum was gently squeezed to extrude a small amount of feces from the perforation site into the peritoneal cavity. The animals were resuscitated with normal saline (50 mL/kg, subcutaneous) immediately and $12 \mathrm{~h}$ after CLP. The sham-operated group was submitted to all surgical procedures, but the cecum was neither ligated nor perforated. The animals were killed by decapitation at 3, 6, and $12 \mathrm{~h}$ after surgery, and the lung was removed for subsequent analyses. The number of animals in each group per experiment was ten. In some experiments, a SOD mimetic was administered once by intra-tracheal instillation immediately after CLP induction $(50 \mathrm{mg} / \mathrm{kg})$, and the lung was removed $24 \mathrm{~h}$ after for subsequent analyses. This mimetic has been previously described by Horn et al. [16].

\section{Total SOD activity}

The SOD activity was measured by inhibition of adrenaline auto-oxidation followed by spectrophotometry as previously described [17]. 


\section{Immunoblotting}

The lung samples were lysed in Laemmli sample buffer $(62.5 \mathrm{mM}$ Tris- $\mathrm{HCl}, \mathrm{pH} 6.8$, $1 \%(w / v)$ SDS, $10 \% v / v)$ glycerol). Protein $(30 \mu \mathrm{g})$ was fractionated by SDSpolyacrylamide gel electrophoresis and then electroblotted onto nitrocellulose membranes. Protein loading and electroblotting efficiencies were verified by Ponceau S staining. The membrane was blocked in Tween-Tris-buffered saline (TTBS, $100 \mathrm{mM}$ Tris- $\mathrm{HCl}, \mathrm{pH} 7.5$, containing $0.9 \% \mathrm{NaCl}$ and $0.1 \%$ Tween-20) containing $5 \%$ albumin. The membranes were incubated overnight at $4^{\circ} \mathrm{C}$ with rabbit polyclonal antibody, targeting SOD1 (Santa Cruz Biotechnology, CA, USA) (dilution range 1:400), SOD2 (Santa Cruz Biotechnology) (dilution range 1:400), SOD3 (Santa Cruz Biotechnology) (dilution range 1:750), iNOS (Santa Cruz Biotechnology) (dilution range 1:400) or anti- $\beta$-actin 1:2000, in the presence of $5 \%$ milk. Thereafter, the membranes were washed with TTBS. Anti-rabbit immunoglobulin G (IgG) peroxidase-linked secondary antibody was incubated (1:10,000 dilution range), and the immunoreactivity was detected by enhanced chemiluminescence using ECL Plus kit (Thermo Fisher Scientific Inc., Pittsburgh, PA, USA). Densitometric analyses of the films were performed with ImageQuant software (GE Healthcare Life Sciences, Billerica, MA, USA). The blots were developed such that the signals are linear and non-saturating which are required for densitometry. All results were expressed as a relative ratio comparing the immunocontent of SOD1, SOD2, SOD3, and iNOS with that of the $\beta$-actin internal control [18].

\section{Enzyme-linked immunosorbent assay to 3-nitrotyrosine contents}

An indirect enzyme-linked immunosorbent assay (ELISA) was performed to analyze the changes in 3-nitrotyrosine content. Briefly, an anti-3-nitrotyrosine polyclonal rabbit antibody (Santa Cruz Biotechnology) was diluted 2,000-fold in PBS with 5\% albumin according to the manufacturer's instructions. Then, microtiter plates (96 wells, with flat bottom) were coated for $24 \mathrm{~h}$ with the samples that had been diluted 1:2 in PBS with 5\% albumin. The plates were washed four times with wash buffer (PBS with 0.05\% Tween-20), and the antibody was added to each plate for $2 \mathrm{~h}$ at room temperature. After washing, a second incubation with anti-rabbit antibody peroxidase conjugate (diluted 1:1,000) was performed for $1 \mathrm{~h}$ at room temperature. After the addition of substrates, the samples were read in a plate spectrophotometer at $450 \mathrm{~nm}$. The results are expressed as changes in the percentage among the groups [19].

\section{Semi-quantitative reverse transcription polymerase chain reaction}

All transcriptional analyses were performed in the samples in which prior Western blotting experiments revealed differences in the immunocontent. The goal was to evaluate the contribution of each gene to transcriptional changes in the immunocontent of each enzyme. Total RNA was isolated from the rat lung using TRIzol ${ }^{\bullet}$ reagent (Invitrogen, Carlsbad, CA, USA), according to the manufacturer's instructions. Using a spectrophotometer, the purity of the RNA was quantified by calculating the ratio between absorbance values at 260 and $280 \mathrm{~nm}$, and its integrity was confirmed by electrophoresis using a 1.0\% agarose gel. Afterward, cDNA species were synthesized using ImProm- II $^{\mathrm{Tm}}$ Reverse Transcription System (Promega ${ }^{\oplus}$, Madison, WI, USA), as described by the supplier's instruction. The cDNA products $(1 \mu \mathrm{L})$ were used as a template for 
each polymerase chain reaction (PCR) amplification. The PCR parameters were first optimized. Thereafter, the reactions were performed, such that product detection could be performed within the linear phase of messenger ribonucleic acid (mRNA) transcript amplification for each primer pair (Table 1). PCR for the $\beta$-actin gene was performed in a total volume of $20 \mu \mathrm{L}$ using $0.1 \mu \mathrm{M}$ of each primer, $0.2 \mu \mathrm{M} \mathrm{dNTP,} 1.6 \mathrm{mM} \mathrm{MgCl}$, and $0.2 \mathrm{U}$ Taq platinum DNA polymerase (Invitrogen). For PCR amplification of sod1, $\operatorname{sod} 2$, and $\operatorname{sod} 3$, the reaction was performed in a total volume of $25 \mu \mathrm{L}$ using $0.2 \mu \mathrm{M}$ of each primer, $0.2 \mu \mathrm{M} d \mathrm{NTP}, 1.6 \mathrm{mM} \mathrm{MgCl}$, and $0.25 \mathrm{U}$ Taq platinum DNA polymerase (Invitrogen). The conditions for $\operatorname{sod} 1$, sod2, and $\operatorname{sod} 3$ PCRs were as follows: initial 1-min denaturation step at $94^{\circ} \mathrm{C}$, another 1 -min denaturation step at $94^{\circ} \mathrm{C}, 1$-min annealing step at $60^{\circ} \mathrm{C}, 1$-min extension step at $72^{\circ} \mathrm{C}$ for 30 cycles, and a final 10 -min extension at $72^{\circ} \mathrm{C}$. The conditions for the $\beta$-actin PCR were as follows: initial 1-min denaturation step at $94^{\circ} \mathrm{C}$, another 1 -min denaturation step at $94^{\circ} \mathrm{C}, 1$-min annealing step at $54^{\circ} \mathrm{C}, 1-\mathrm{min}$ extension step at $72^{\circ} \mathrm{C}$ for 35 cycles, and a final 10 -min extension at $72^{\circ} \mathrm{C}$. For each PCR set, a negative control was included. The PCR products were then analyzed on a $1 \%$ agarose gel containing GelRed ${ }^{\circ}$ (Biotium, Hayward, CA, USA) and visualized with ultraviolet light. The Low DNA Mass Ladder (Invitrogen) was used as a molecular marker, and the samples were normalized against the constitutively expressed $\beta$-actin gene. The band intensities were measured by optical densitometry analysis, and the enzyme/ $\beta$-actin mRNA ratios were established for each treatment using the freeware Image J 1.37. Each experiment was repeated at least four times using RNA isolated from independent extractions.

\section{Immunohistochemistry}

Lung sections (sham 0 and 12 and CLP 0 and 12, $n=3$ in each group) were deparaffinized and hydrated. To examine their histological features, the lungs were stained with hematoxylin and eosin (H\&E). After blocking of endogenous peroxidase, antigen retrieval was performed in a high-temperature Tris-citrate buffer ( $\mathrm{pH}$ 7.2). The rabbit polyclonal anti-SOD3 (Santa Cruz Biotechnology) (diluted 1:1,600) was used as the primary antibody. The Vectastin ABC Kit (Vector Laboratories, Burlingame, CA, USA) was used as the secondary antibody, and 3,3-diaminobenzidine (DAB, Sigma, St. Louis, MO, USA) was used as the chromogen. Thereafter, the sections were counterstained with Harris hematoxylin (Merck, Darmstadt, Germany). In the negative controls, the first antibody was omitted from the procedure, and the tissues were incubated with bovine serum albumin (BSA) instead.

Table 1 PCR primer design

\begin{tabular}{|c|c|c|c|c|}
\hline Enzymes & Primer sequences $\left(5^{\prime}-3^{\prime}\right)$ & $\begin{array}{l}\text { Anneling } \\
\text { temperature }\left({ }^{\circ} \mathrm{C}\right)\end{array}$ & $\begin{array}{l}\text { PCR product } \\
\text { (bp) }\end{array}$ & $\begin{array}{l}\text { GenBank accession } \\
\text { number (mRNA) }\end{array}$ \\
\hline \multirow[t]{2}{*}{ sod 1} & F-TGCGTGCTGAAGGGCGACGGTC & 60 & 438 & BC082800 \\
\hline & R-AATCCCAATCACACCACAAGCCAAGC & & & \\
\hline \multirow[t]{2}{*}{$\operatorname{sod} 2$} & F-CCTACGTGAACAATCTGAACGTCACCGAG & 60 & 373 & BC070913.1 \\
\hline & R-CCCAGCAGTGGAATAAGGCCTGTGG & & & \\
\hline \multirow[t]{2}{*}{ sod3 } & F-GCCGAGCAGAACACCTCCAACCACG & 60 & 377 & BC061861.1 \\
\hline & R-CGCCGCTTCTTGCGCTCCTTG & & & \\
\hline \multirow[t]{2}{*}{$\beta$-actin } & F-TATGCCAACACAGTGCTGCTGG & 54 & 210 & $N P \_742006$ \\
\hline & R-TACTCCTGCTTCCTGATCCACAT & & & \\
\hline
\end{tabular}




\section{Cytokine determination}

Lung levels of tumor necrosis factor (TNF)- $\alpha$, interleukin (IL)-1 $\beta$, IL-6, and IL-10 were determined by ELISA according to the manufacturer's instructions (PrepoTech, Ribeirão Preto, SP, Brazil). All samples were assayed in duplicate.

\section{Lung permeability assay}

Permeability changes were measured by Evan's blue dye (EBD) leakage from the blood into the airways. EBD (20 mg/kg) was administered by femoral vein injection $1 \mathrm{~h}$ before the end of the experiments. One hour later, the mice were bled by cardiac puncture, and the pulmonary vasculature was flushed by right ventricle puncture. The pulmonary vessels were perfused with normal saline to remove EBD from the vascular spaces. The lungs were removed en bloc and dried at $60^{\circ} \mathrm{C}$ for $24 \mathrm{~h}$. EBD was extracted in formamide at $37^{\circ} \mathrm{C}$ for $24 \mathrm{~h}$ and quantitated by its fluorescence intensity. The extravasated EBD concentration in lung homogenate was calculated against a standard curve.

\section{Statistical analysis}

Data are expressed as mean \pm standard deviation. The means for the different groups were compared by $t$ test or one-way or two-way ANOVA followed by Tukey test, depending on the number of experimental groups. Statistical significance was assigned to $p<0.05$.

\section{Results}

Levels of SOD were determined in the lung 3 to $12 \mathrm{~h}$ after sepsis. There was a decrease in the immunocontent of SOD1 at 3 and 12 hours, but not at $6 \mathrm{~h}$, after sepsis induction (Figure 1A,B,C). Furthermore, an increase in the immunocontent of SOD2 was observed at all times (Figure $2 \mathrm{~A}, \mathrm{~B}, \mathrm{C}$ ), and there was an increase in the immunocontent of SOD3 at 6 and $12 \mathrm{~h}$ after sepsis induction (Figure 3A,B,C). The SOD activity increased
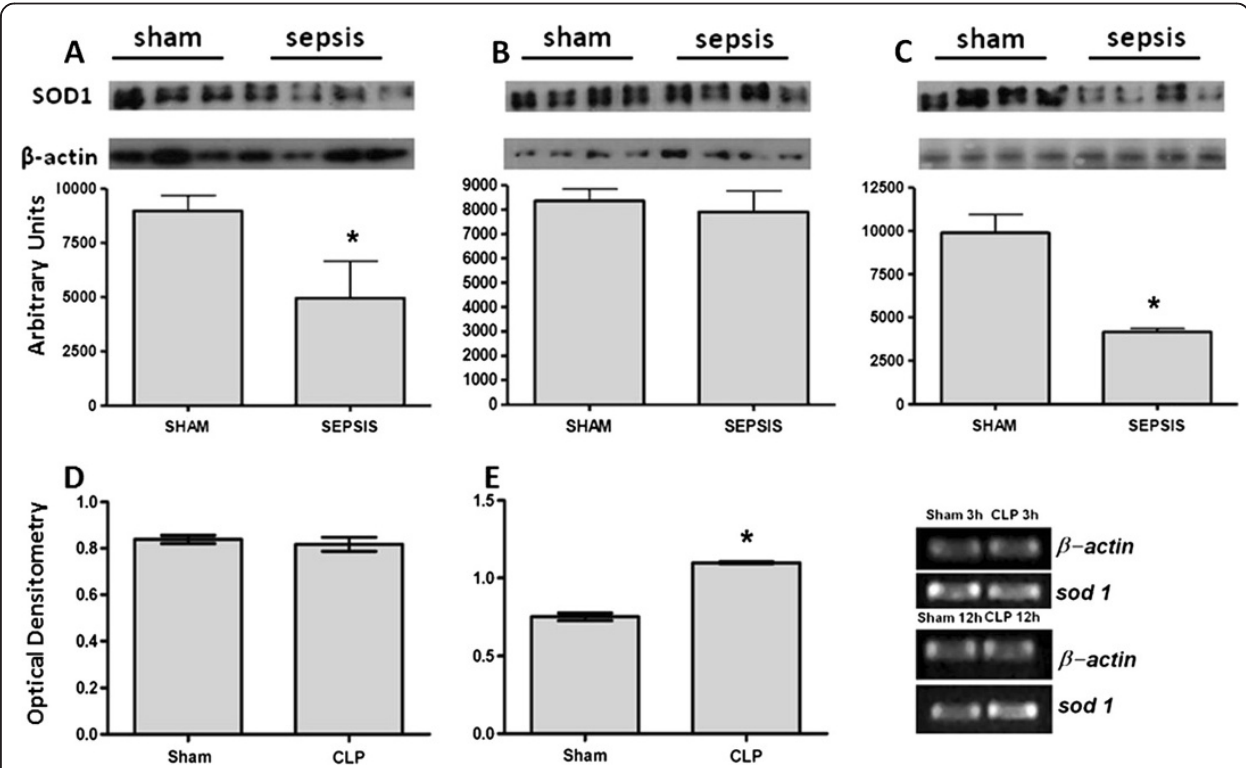

Figure 1 Cytosolic superoxide dismutase (SOD1) alterations early after sepsis induction. The animals were submitted to sepsis or sham-operated, and $3 \mathrm{~h}(\mathbf{A}), 6 \mathrm{~h}$ (B), and $12 \mathrm{~h}$ (C) after surgery, the immunocontent of SOD1 was evaluated. The sod1 gene expression was evaluated at $3 \mathrm{~h}$ (D) and $12 \mathrm{~h}$ (E) after surgery. The data are expressed as mean \pm SD ( $n=$ ten animals/group). $p$ value $<0.05$ was considered significant when compared to the control. * denotes $p<0.05$. 

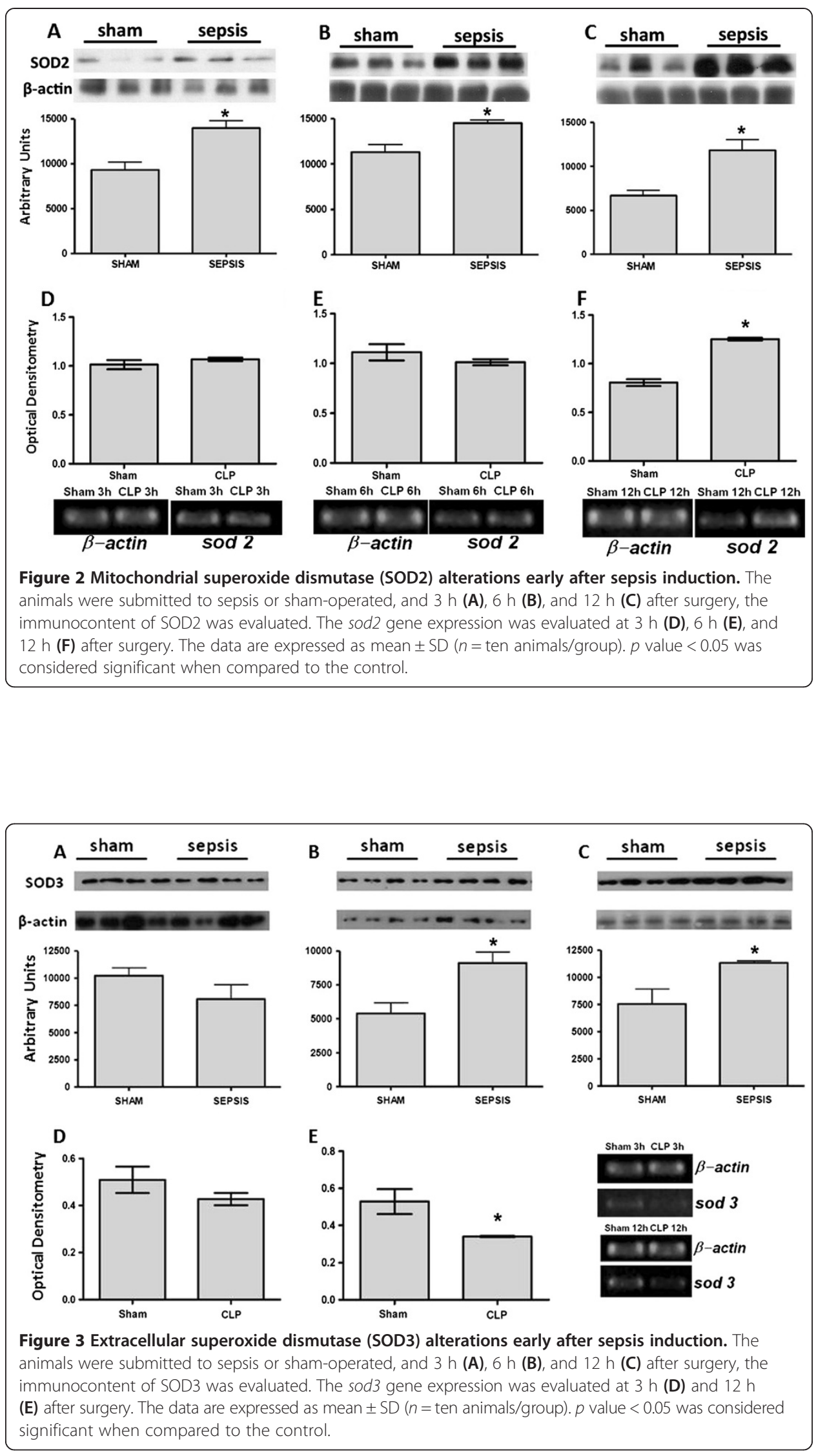


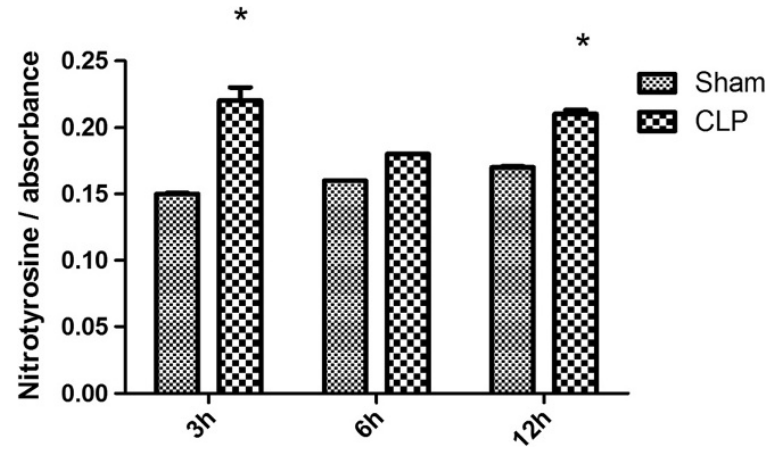

Figure 4 Nitrotyrosine content early after sepsis induction. The animals were submitted to sepsis or sham-operated, and 3, 6, and $12 \mathrm{~h}$ after surgery, the content of nitrotyrosine was evaluated. The data are expressed as mean \pm SD ( $n=$ ten animals/group). $p$ value $<0.05$ was considered significant when compared to the control.

at 6 and $12 \mathrm{~h}(6 \mathrm{~h}, 6.03 \pm 2.1$ vs. $21.1 \pm 5.6, p=0.02 ; 12 \mathrm{~h}, 4.9 \pm 1.7$ vs. $22.3 \pm 7.6 \mathrm{U} / \mathrm{mg}$ protein, $p=0.01$ ) when compared to the sham and CLP animals, respectively. To determine if these changes of protein content were associated with alterations in gene expression, semi-quantitative reverse transcription polymerase chain reaction (RT-PCR) was performed. There was no consistent pattern of gene expression; while sod 1 and sod2 gene expressions increased $12 \mathrm{~h}$ after sepsis (Figure 1D,E and Figure 2D,E,F), sod3 gene expression decreased at this time point (Figure 3B).

Nitrotyrosine levels increased 3 and 12 hours after CLP induction (Figure 4), suggesting that despite the increase of SOD3 content the reaction between superoxide and NO was occurring. Lung content of iNOS did not increase in the lung of septic animals (Figure 5A-C), but it was increased in the pulmonary artery (Figure 5D-E).

These alterations were associated with capillary congestion and infiltration of neutrophils into the alveolar septa (Figure 6). It was possible that the increase in SOD3 protein content did not protect the lung from oxidant injury due to a disorganized distribution resulting from proteolytic cleavage of its heparin-binding domain, but SOD
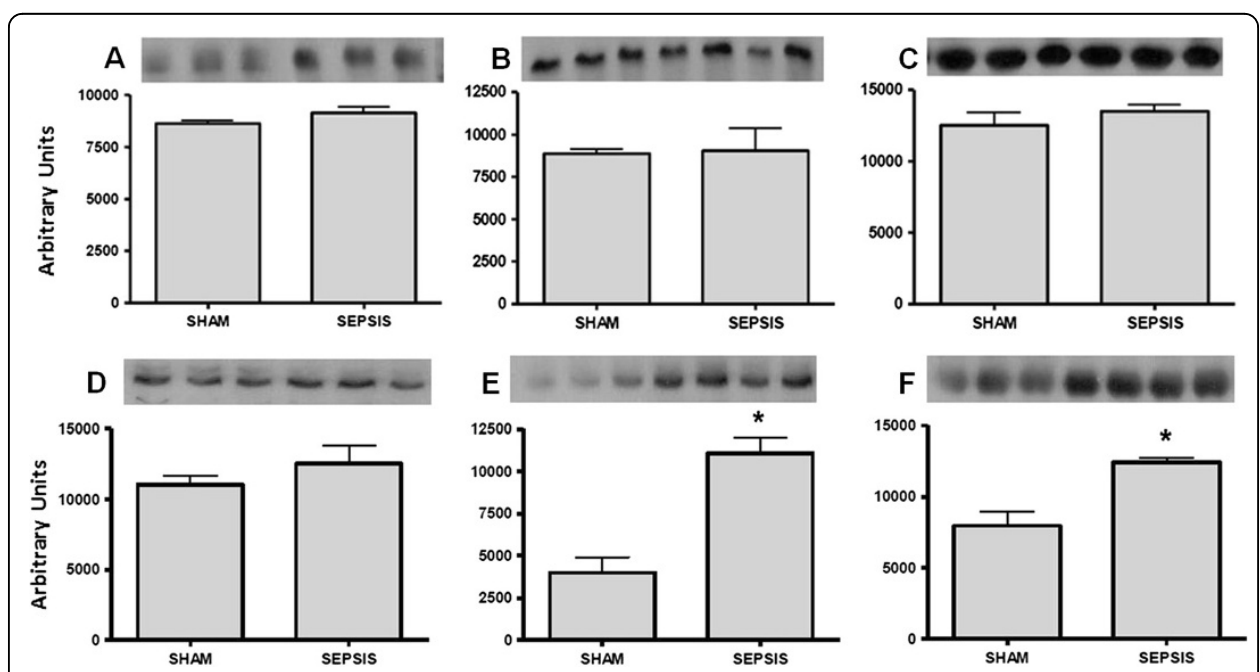

Figure 5 Inducible nitric oxide synthase (iNOS) alterations early after sepsis induction. The animals were submitted to sepsis or sham-operated, and $3 \mathrm{~h}$ (A), $6 \mathrm{~h}$ (B), and $12 \mathrm{~h}$ (C) after surgery, the immunocontent of iNOS was evaluated in the lung and in the pulmonary artery $(3 \mathrm{~h}(\mathbf{D}), 6 \mathrm{~h} \mathrm{(E)}, 12 \mathrm{~h}(\mathbf{F}))$. The data are expressed as mean \pm SD ( $n=$ ten animals/group). $p$ value $<0.05$ was considered significant when compared to the control. 


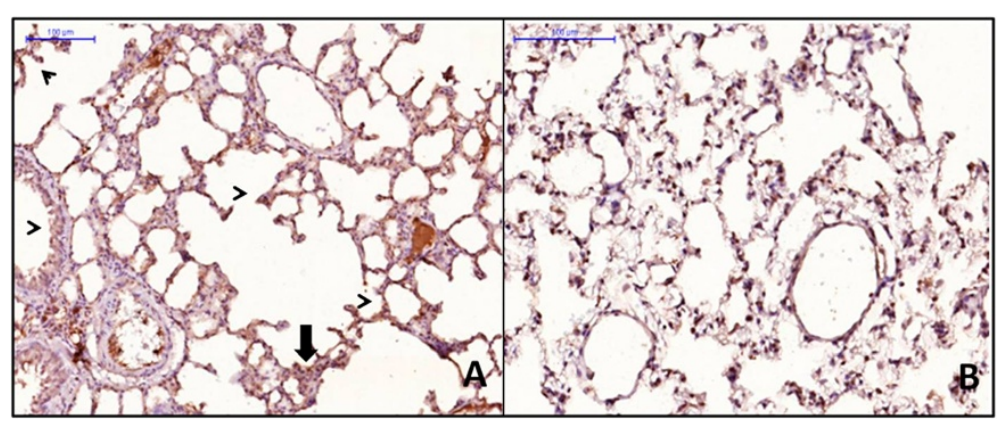

Figure 6 Distribution of extracellular superoxide dismutase (SOD3) in the lung early after sepsis. The animals were submitted to sepsis or sham-operated, and $12 \mathrm{~h}$ after surgery, the distribution of lung SOD3 was determined by immunohistochemistry. Representative photographs of septic (A) and sham (B) animals. Original magnification is $\times 6,200$.

was adequately distributed across the lung (Figure 6). It was expressed mainly in the bronchial and alveolar epithelia of the CLP animals and to a minor extent in the leukocytes and endothelial cells (Figure 6).

It was expected that SOD3 protected the lung from oxidative damage and inflammation, but this was not supported by the presented data. Thus, it was administered a SOD mimetic, and it decreased the lung nitrotyrosine and cytokine levels, as well as preserved lung permeability (Figure 7A,B,C).

\section{Discussion}

Here, in a CLP model, we demonstrated that during sepsis development, the levels of SOD2 and SOD3 increased in the lung, but these did not prevent nitrosative damage and inflammation. Furthermore, we showed that superoxide-derived lung inflammation could be attenuated by the administration of an exogenous SOD mimetic.

An increase in the levels of SOD2 and SOD3 was observed; thus, it was believed that the lung was protected from superoxide-derived oxidative damage. SOD3 is a potent inhibitor of inflammation in lung injury models [20], and mice lacking the sod3 gene are more sensitive to lethal levels of hyperoxia [14]. Furthermore, SOD3 protects against endothelial dysfunction in mice treated with endotoxin [21]. In a murine model of emphysema, the mice that overexpress the sod3 gene or are treated with a SOD mimetic have improved lung compliance, decreased neutrophil influx, release of proinflammatory mediators, and oxidative damage [22]. Here, we show that despite the increase in SOD content, there is an increase in lung nitrotyrosine content.

In general, inflammatory conditions (including lipopolysaccharide, hypoxia, asbestos exposure, bleomycin, and hyperoxia) induce a decrease in SOD3 content. This observation is most likely a result of proteolysis of its heparin-binding domain rather than alterations in its gene expression [20,23]. In contrast, at earlier time points after sepsis induction, we demonstrate an increase in SOD3 levels that are properly distributed throughout the lung parenchyma, but this is not sufficient to prevent the formation of peroxynitrite. Increased oxidative damage, despite the presence of higher levels of SOD3, was described in a model of cerebral ischemia [24].

The reaction of $\mathrm{NO}$ with superoxide may lead to an increase in $\mathrm{ONOO}^{-}$, which mediates nitration of tyrosine residues in certain enzymes, including SODs. This modification leads to a reduction in their activity and, as a result, further increase in superoxide 


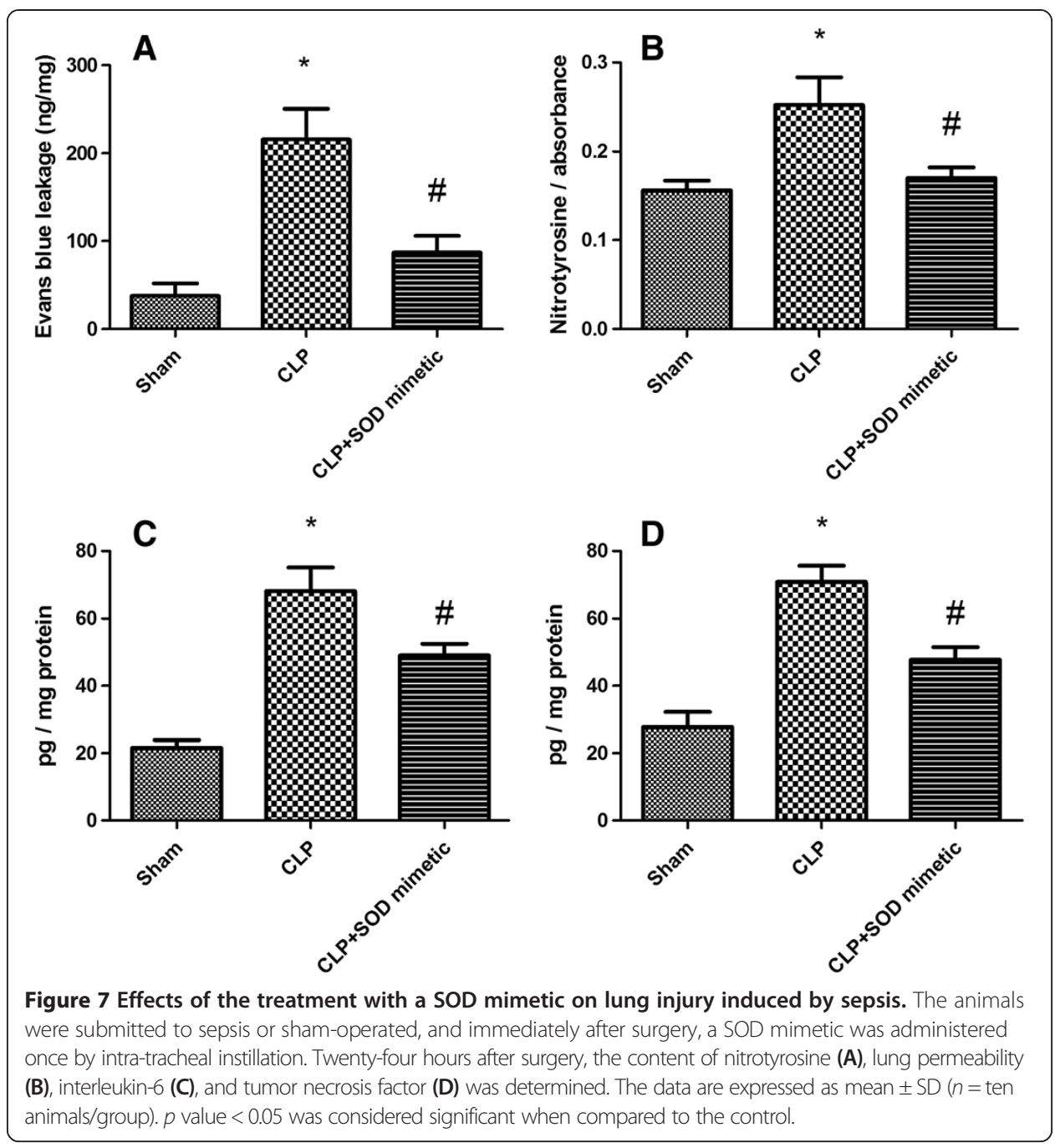

levels [25]. Specifically, $\mathrm{ONOO}^{-}$is known to inactivate SOD1 and SOD2 [26,27]. Due to the structural similarity between SOD1 and SOD3, we speculate that the activity of SOD3 may similarly be decreased by $\mathrm{ONOO}^{-}$. Here, we demonstrate that septic animals have increased levels of nitrotyrosine. This occurs even in the presence of higher SOD3 levels and total SOD activity. This pattern is not expected since in different models, an increase in SOD3 activity is usually associated with a decrease in $\mathrm{ONOO}^{-}$ [28]. However, when we used an exogenous SOD mimetic, it is observed that there is a decrease in the nitrotyrosine levels. These observations suggest that the endogenous SOD system is not able to prevent oxidative damage in the CLP model. In addition, a SOD mimetic decreased the markers of lung inflammation and improved lung permeability. Moreover, these findings raise the possibility that SOD mimetics could be used to treat sepsis-related lung injury.

There are some limitations to our study. Firstly, SOD mimetic was administered immediately after CLP, when the septic response was not fully developed and animals did not presented clinical signs of severe infection. Thus, this design did not reflect the clinical scenario, but can be relevant to understand the mechanisms associated with sepsis development. Secondly, nitrotyrosine was not measured by gold-standard 
techniques, such as tandem mass spectrometry or high-performance liquid chromatography. Since the increase of nitrotyrosine is classically found in sepsis models, the use of semi-quantitative ELISA as a marker of oxidative damage seems to be adequate to the study aim.

\section{Conclusions}

In conclusion, this study demonstrated an increase in SOD3 levels following sepsis; however, this was not able to prevent oxidative stress and inflammation associated with $\mathrm{ONOO}^{-}$production. Nonetheless, the administration of a SOD mimetic had a positive impact, which suggests that administration of exogenous SOD may improve lung function in sepsis.

\section{Competing interests}

The authors declare that they have no competing interests.

\section{Authors' contributions}

LC, MRB, JCFM, AH, TM, CR, and FD-P conceived this study, participated in the design of the study, and drafted the manuscript. RCG, VRG, CDT, FV, LWK, GMTO, MABP, KVM, and CF participated in the design of the study and in the collection of data. All authors read and approved the final manuscript.

\section{Acknowledgements}

This research was supported by grants from CAPES, FAPESC, UNESC, and CNPq-Instituto Nacional de Ciência e Tecnologia Translacional em Medicina (INCT-TM). Further acknowledgment is expressed to all authors who contributed to this study.

\section{Author details \\ ${ }^{1}$ Laboratório de Fisiopatologia Experimenta e Instituto Nacional de Ciência e Tecnologia Translacional em Medicina (INCT-TM), Programa de Pós-Graduação de Ciências da Saúde, Universidade do Extremo Sul Catarinense, Avenida Universitária, 1105, Criciúma, SC 88806-000, Brazil. ${ }^{2}$ Laboratório de Biologia Genômica e Molecular e INCT-TM, Faculdade de Biociências, Pontifícia Universidade Católica do Rio Grande do Sul, Avenida Ipiranga, 6681, Porto Alegre, RS 90619-900, Brazil. ${ }^{3}$ Departamento de Bioquímica, Centro de Estudos em Estresse Oxidativo, ICBS, Universidade Federal do Rio Grande do Sul, Rua Ramiro Barcelos, 2600-Anexo, Porto Alegre, RS CEP 90035-003, Brazil. ${ }^{4}$ Departmento de Patologia, Faculdade de Medicina, Universidade de São Paulo, São Paulo, SP 05508-070, Brazil. ${ }^{5}$ Laboratório de Ciências Químicas, Universidade Estadual do Norte Fluminense, Campos dos Goytacazes, RJ 28013-602, Brazil.}

Received: 7 April 2014 Accepted: 7 April 2014

Published: 23 May 2014

\section{References}

1. Salvemini D, Cuzzocrea S (2002) Oxidative stress in septic shock and disseminated intravascular coagulation. Free Radic Biol Med 33(9):1173-1185

2. Powell CS, Jackson RM (2003) Mitochondrial complex I, aconitase, and succinate dehydrogenase during hypoxia-reoxygenation: modulation of enzyme activities by MnSOD. Am J Physiol Lung Cell Mol Physiol 285:189-198. doi:10.1152/ajplung.00253.2002

3. Kurosaki M, Li Calzi M, Scanziani E, Garattini E, Terao M (1995) Tissue- and cell-specific expression of mouse xanthine oxidoreductase gene in vivo: regulation by bacterial lipopolysaccharide. Biochem J 306(1):225-234

4. Dahl M, Bauer AK, Arredouani M, Soininen R, Tryggvason K, Kleeberger SR, Kobzik L (2007) Protection against inhaled oxidants through scavenging of oxidized lipids by macrophage receptors MARCO and SR-AI/II. J Clin Invest 117:757-764. doi:10.1172/JCI29968

5. Kliment CR, Tobolewski JM, Manni ML, Tan RJ, Enghild J, Oury TD (2008) Extracellular superoxide dismutase protects against matrix degradation of heparan sulfate in the lung. Antioxid Redox Signal 10:261-268. doi:10.1089/ars.2007.1906

6. Kinnula VL, Crapo JD (2003) Superoxide dismutases in the lung and human lung diseases. Am J Respir Crit Care Med 167:1600-1619. doi:10.1164/rccm.200212-1479SO

7. Clarke MB, Wright R, Irwin D, Bose S, Van Rheen Z, Birari R, Stenmark KR, McCord JM, Nozik-Grayck E (2010) Sustained lung activity of a novel chimeric protein, SOD2/3, after intratracheal administration. Free Radic Biol Med 49:2032-2039. doi:10.1016/j.freeradbiomed.2010.09.028

8. Gongora MC, Lob HE, Landmesser U, Guzik TJ, Martin WD, Ozumi K, Wall SM, Wilson DS, Murthy N, Gravanis M, Fukai T, Harrison DG (2008) Loss of extracellular superoxide dismutase leads to acute lung damage in the presence of ambient air: a potential mechanism underlying adult respiratory distress syndrome. Am J Pathol 173 (4):915-926. doi:10.2353/ajpath.2008.080119

9. Dahl M, Bowler RP, Juul K, Crapo JD, Levy S, Nordestgaard BG (2008) Superoxide dismutase 3 polymorphism associated with reduced lung function in two large populations. Am J Respir Crit Care Med 178:906-912. doi:10.1164/rccm.200804-5490C

10. Gao F, Kinnula VL, Myllärniemi M, Oury TD (2008) Extracellular superoxide dismutase in pulmonary fibrosis. Antioxid Redox Signal 10(2):343-354. doi:10.1089/ars.2007.1908 
11. Oury TD, Day BJ, Crapo JD (1996) Extracellular superoxide dismutase: a regulator of nitric oxide bioavailability. Lab Invest 75:617-636

12. Hayreh SS, Piegors DJ, Heistad DD (1997) Serotonin-induced constriction in ocular arteries in atherosclerotic monkeys: implications for ischemic disorders of the retina and optic nerve head. Arch Ophthalmol 115:220-228

13. Heistad DD, Paul M, Endothelial function in the time of the giants (2008) Vanhoutte Lecture. J Cardiovasc Pharmacol 52(5):385-392. doi:10.1097/FJC.0b013e31818a403b

14. Carlsson LM, Jonsson J, Edlund T, Marklund SL (1995) Mice lacking extracellular superoxide dismutase are more sensitive to hyperoxia. Proc Natl Acad Sci USA 92:6264-6268

15. Ritter C, Andrades M, Frota Júnior ML, Bonatto F, Pinho RA, Polydoro M, Klamt F, Pinheiro CT, Menna-Barreto SS, Moreira JC, Dal-Pizzol F (2003) Oxidative parameters and mortality in sepsis induced by cecal ligation and perforation. Intensive Care Med 29(10):1782-1789. doi:10.1007/s00134-003-1861-5

16. Horn A Jr, Parrilha GL, Melo KV, Fernandes C, Horner M, Visentin Ldo C, Santos JA, Santos MS, Eleutherio EC, Pereira MD (2010) An iron-based cytosolic catalase and superoxide dismutase mimic complex. Inorg Chem 49 (4):1274-1276. doi:10.1021/ic901904b

17. Bannister JV, Calaberese L (1987) Assays for SOD. Methods Biochem Anal 32:279-312

18. Pasquali MAB, Gelain DP, Oliveira MR, Behr GA, Motta LL, Rocha RF, Klamt F, Moreira JC (2009) Vitamin A supplementation induces oxidative stress and decreases the immunocontent of catalase and superoxide dismutase in rat lungs. Exp Lung Res 35:427-438

19. Oliveira MR, Lorenzi R, Schnorr CE, Morrone M, Moreira JC (2011) Increased 3-nitrotyrosine levels in mitochondrial membranes and impaired respiratory chain activity in brain regions of adult female rats submitted to daily vitamin A supplementation for 2 months. Brain Res Bull 86:246-253, doi:1016/j.brainresbull.2011.08.006

20. Bowler RP, Nicks M, Tran K, Tanner G, Chang LY, Young SK, Worthen GS (2004) Extracellular superoxide dismutase attenuates lipopolysaccharide-induced neutrophilic inflammation. Am J Respir Cell Mol Biol 31(4):432-439. doi:10.1165/rcmb.2004-00570C

21. Lund DD, Chu Y, Brooks RM, Faraci FM, Heistad DD (2007) Effects of a common human gene variant of ECSOD on endothelial function after endotoxin in mice. J Physiol 584(2):583-590. doi:10.1113/jphysiol.2007.140830

22. Yao H, Arunachalam G, Hwang J, Chung S, Sundar IK, Kinnula VL, Crapo JD, Rahman I (2010) Extracellular superoxide dismutase protects against pulmonary emphysema by attenuating oxidative fragmentation of ECM. Proc Nat Acad Sci USA 107(35):15571-15576. doi:10.1073/pnas.1007625107

23. Oury TD, Schaefer LM, Fattman CL, Choi A, Weck KE, Watkins SC (2002) Depletion of pulmonary EC-SOD after exposure to hyperoxia. Am J Physiol Lung Cell Mol Physiol 283:L777-L784. doi:10.1152/ajplung.00011.2002

24. Fukui S, Ookawara T, Nawashiro H, Suzuki K, Shima K (2002) Post-ischemic transcriptional and translational responses of EC-SOD in mouse brain and serum. Free Radic Biol Med 32(3):289-298. doi:10.1016/50891-5849(01)00804-8

25. Van der Loo B, Labugger R, Skepper JN, Bachschmid M, Kilo J, Powell JM, Palacios-Callender M, Erusalimsky JD, Quaschning T, Malinski T, Gygi D, Ullrich V, Lüscher TF (2000) Enhanced peroxynitrite formation is associated with vascular aging. J Exp Med 192:1731-1744. doi:10.1084/jem.192.12.1731

26. Alvarez B, Demicheli V, Duran R, Trujillo M, Cerveñansky C, Freeman BA, Radi R (2004) Inactivation of human Cu, Zn superoxide dismutase by peroxynitrite and formation of histidinyl radical. Free Radic Biol Med 37:813-822. doi:10.1016/j.freeradbiomed.2004.06.006

27. Sun D, Huang A, Yan EH, Wu Z, Yan C, Kaminski PM, Oury TD, Wolin MS, Kaley G (2004) Reduced release of nitric oxide to shear stress in mesenteric arteries of aged rats. Am J Physiol Heart Circ Physiol 286:H2249-H2256. doi:10.1152/ajpheart.00854.2003

28. lida S, Chu Y, Weiss RM, Kang YM, Faraci FM, Heistad DD (2006) Vascular effects of a common gene variant of extracellular superoxide dismutase in heart failure. Am J Physiol Heart Circ Physiol 291(2):H914-H920. doi:10.1152/ajpheart.00080.2006

doi:10.1186/2197-425X-2-17

Cite this article as: Constantino et al:: Regulation of lung oxidative damage by endogenous superoxide dismutase in sepsis. Intensive Care Medicine Experimental 2014 2:17.

\section{Submit your manuscript to a SpringerOpen ${ }^{\circ}$ journal and benefit from:}

- Convenient online submission

- Rigorous peer review

- Immediate publication on acceptance

- Open access: articles freely available online

- High visibility within the field

- Retaining the copyright to your article

Submit your next manuscript at $\boldsymbol{\sim}$ springeropen.com 